\title{
Relationship between Video Head Impulse Gain and Severity of Dizziness in Patients with Vestibular Neuritis
}

\author{
Sung Hoon Nam, Yong Han Kim, Woo Ri Choi, Yehree Kim, Ja Yoon Ku, and Hong Ju Park \\ Department of Otorhinolaryngology-Head and Neck Surgery, Asan Medical Center, University of Ulsan College of Medicine, \\ Seoul, Korea
}

전정신경염 환자에서 비디오 두부충동검사의 이득과 어지럼증의 정도와의 연관성

남성훈 · 김용한 · 최우리 · 김예리 · 구자윤 · 박홍주

울산대학교 의과대학 서울아산병원 이비인후-두경부외과학교실

Received April 18, 2018

Revised August 3,2018

Accepted October 5, 2018

Address for correspondence

Hong Ju Park, MD, PhD

Department of Otorhinolaryngology-

Head and Neck Surgery,

Asan Medical Center,

University of Ulsan

College of Medicine,

88 Olympic-ro 43-gil, Songpa-gu,

Seoul 05505 , Korea

Tel $+82-2-3010-3700$

Fax $+82-2-489-2773$

E-mail dzness@amc.seoul.kr
Background and Objectives We evaluated the correlation between video head impulse test (vHIT) and dizziness handicap inventory (DHI), which is commonly used to quantify severity of dizziness in vestibular neuritis (VN).

Subjects and Method Twenty VN patients undergoing vHIT either at the acute or follow-up stages of treatment were assessed by DHI questionnaire. Gain and gain asymmetry (GA) were correlated with DHI scores and abnormal vHIT rates were compared according to the severity of dizziness (mild $\leq 30$; moderate-to-severe $\geq 32$ ).

Results vHIT gains significantly increased from the acute to follow-up stages (from $0.45 \pm$ 0.18 to $0.70 \pm 0.25$ ), whereas GA and DHI scores decreased (GA, from $0.36 \pm 0.15$ to $0.22 \pm 0.18$; DHI scores, from $35 \pm 26$ to $23 \pm 23$ ). Although vHIT gains or GA showed no correlation with DHI scores at the acute stage, vHIT gains showed significant correlation with DHI scores at the follow-up (R-sq=0.32, $p=0.01$ ) stage. vHIT gains and GA did not differ according to the severity of dizziness during the acute stage; however, vHIT gains $(0.78 \pm 0.25)$ of patients with mild dizziness were significantly higher than those $(0.51 \pm 0.14)$ with moderate-to-severe dizziness at the follow-up stage. During the follow-up, all patients with moderate-to-severe dizziness showed abnormal vHIT gain, but $43 \%$ of patients with mild dizziness showed abnormal vHIT gain, showing a significant difference $(p<0.05)$.

Conclusion Reduced vHIT gain was significantly correlated with high degrees of dizziness at the follow-up, but not at the acute stage, suggesting that high-frequency canal dysfunction is contributed in part by the subjective dizziness at the follow-up. Our findings suggest that vHIT might give an indirect evidence for implementing vestibular rehabilitation for enhancing impaired vestibular function and relieving subjective dizziness.

Korean J Otorhinolaryngol-Head Neck Surg 2019;62(5):277-83

Key Words Dizziness handicap inventory · Gain · Head impulse test · Vestibular neuritis.

\section{서 론}

비디오 두부충동검사(video head impulse test, vHIT)는

This is an Open Access article distributed under the terms of the Creative Commons Attribution Non-Commercial License (https://creativecommons.org/licenses/by-nc/4.0) which permits unrestricted non-commercial use, distribution, and reproduction in any medium, provided the original work is properly cited.
반고리관의 전정안반사 기능을 확인할 수 있는 검사로, 고주 파수 고가속도의 머리회전자극에 대한 전정안반사의 결과인 안구의 보상적인 운동 정도를 확인하여 정량적으로 전정안 반사의 손상 여부를 확인할 수 있는 검사이다. ${ }^{1-3)}$ 각막에 코 일을 위치하여 안구의 움직임을 기록하는 고전적인 방법에 서 보다 진보하여 비디오를 이용하여 안구의 움직임을 측정 
함으로써 머리회전자극에 대한 보상적인 안구의 움직임을 확인하게 된 이후 많은 전정질환에서 비디오 두부충동검사가 사용되어 왔다.,4-7) 일측 전정신경의 기능이 급성으로 소실되 는 전정신경염 환자에서는 병변쪽으로 머리를 급속히 회전시 킬 경우 반대쪽으로 향하는 보상적인 완서상 안구운동이 불 충분하게 되어 전정안반사의 이득이 감소하게 되고, 머리 회 전이 끝난 후에 이러한 이득이 감소로 인해 발생하는 망막 미 끄러짐(retinal slip)을 보상하기 위해 보상적 단속운동(corrective saccade)에 의해 안구가 급속히 놓쳤던 목표물을 볼 수 있게 된다. 따라서, 전정신경염 환자에서 일반적으로 관찰되 는 병적 소견은 비디오 두부충동검사 이득의 감소와 보상적 단속운동의 관찰이다.,8-10)

일반적으로 이러한 전정기능의 손상에 의해 어지럼증이 발 생하고, 이러한 손상이 전정보상기전을 통해 회복됨에 따라 어지럼증의 증상도 점차 호전된다. 전정신경염 환자의 경우 대 부분의 경우 시간이 흐름에 따라 어지럼증 증상의 호전을 보 이는 것으로 알려져 있으나, 13 50\%의 환자에서는 주관적인 어지럼증이 장기적으로 남는 것으로 보고된다. ${ }^{11-13)}$ 전정안반 사와 전정척수반사의 회복은 중추성 안구운동 및 자세유지 반응의 재구성이나, 경부안반사, 보상성 단속운동, 시각 및 체 성감각을 이용한 보상 등의 기전에 의해 발생하나, 전정재활 운동을 통한 손상된 전정기능의 회복이 어지럼증 증상의 호 전과 기능적 회복에 있어서 가장 중요한 기전으로 보고된다.14)

따라서, 외래에서 쉽게 사용하여 전정기능의 손상 정도를 정량적으로 확인할 수 있는 비디오 두부충동검사의 결과와 어지럼증 증상의 정도와의 연관성이 확인될 경우, 비디오 두 부충동검사 결과는 전정재활운동의 필요성을 확인하기 위해 객관적인 지표로써 사용될 수 있는 장점이 있으리라 생각된 다. 임상적으로 전정신경염 환자에서 비디오 두부충동검사 를 통한 전정안반사의 소실 정도와 어지럼증 증상의 정도와 의 연관성을 확인하여 전정기능검사 결과를 이용하여 전정 재활치료의 필요성을 확인할 수 있다는 보고가 있으나, ${ }^{15)}$ 몇 몇 연구에서는 증상의 호전과 전정기능검사 결과와의 연관 성이 높지 않은 것으로도 보고된다. ${ }^{16,17)}$ 따라서, 이러한 비디오 두부충동검사의 결과와 어지럼증 증상의 정도와의 연관성을 확인하고자 하는 추가 연구가 필요한 것으로 생각된다.

따라서, 본 연구에서는 일측성 전정신경염 환자를 대상으 로 입원 중인 급성기와 외래 추적관찰 중에 시행된 비디오 두 부충동검사 결과와 어지럼증의 정도를 정량화한 dizziness handicap inventory(DHI) 점수를 분석하여, 병변의 발생 후 시간의 흐름에 따른 비디오 두부충동검사 결과의 변화 양상과 주관적 어지럼증의 정도와의 상호 연관관계를 확인하고자 한다.

\section{대상 및 방법}

\section{대 상}

전정신경염으로 치료받은 환자 중 입원 중 및 퇴원 후 외래 추적관찰 중 비디오 두부충동검사(vHIT) 검사를 시행한 환자

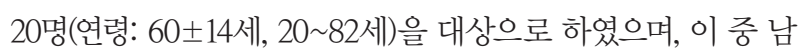
자는 11 명, 여자는 9 명이었다. 전정신경염의 진단은 24 시간 지 속되는 심한 어지럼증과 한쪽을 향하는 수평회전성 자발 안 진이 관찰되고, 온도안진검사로 평가한 편측 마비(unilateral weakness)가 20\% 이상의 전정기능의 손상을 보일 경우로 진 단하였다. 기타 청각 증상이나 다른 신경학적 증상은 관찰되 지 않았으며, 뇌 MRI 검사에서도 정상 소견을 보였다. 전정 기능검사와 어지럼증 설문지는 입원 중에 검사하였으며, 첫 번 째 검사는 증상이 어느 정도 호전된 후(4 \pm 5 일)에 어지럼증 정 도를 확인하기 위한 설문지(DHI 설문지), 온도안진검사와 $\mathrm{vHIT}$ 검사를 시행하였다. 외래 관찰 중( $38 \pm 8$ 일)에 두 번째 $\mathrm{vHIT}$ 검사와 설문지 검사를 시행하였다. 본 연구 프로토콜은 본원 임상연구심의위원회(Institutional Review Board)의 승인을 얻었으며(2014-0136), 헬싱키선언(Declaration of Helsinki) 을 준수하였다.

\section{비디오 두부충동검사(video head impulse test, vHIT)}

비디오 두부충동검사는 수평 방향으로 두부충동을 시행 하였으며 비디오 두부충동검사 기기는 ICS Impulse ${ }^{\circledR}(\mathrm{GN}$ Otometrics, Taastrup, Denmark)를 사용하였다. 안구의 움 직임의 측정은 우측 안구에서만 시행되었다. 머리의 회전은 양쪽으로 각각 5 10 (최고 머리 회전속도, 200 250 deg/sec) 의 급속한 회전자극을 최소 10 회씩 주었으며, 환자는 100 $\mathrm{cm}$ 앞에 위치한 LED 불빛에 시선을 고정하도록 한 후에 검 사자가 피실험자의 뒤쪽에서 환자의 머리를 잡은 상태로 환 자가 방향과 시간을 예상하지 못하도록 무작위적으로 시행하 였다.

이득(vHIT gain)은 머리가 움직이는 정도와 안구의 움직이 는 정도를 비교하여 계산되며, 기기에 내장된 프로그램을 이 용하여 구하였다. 이득은 시간에 따른 머리와 안구의 속도를 측정하여 머리 회전운동이 시작된 후 머리의 운동속도가 0 이 되는 점까지의 머리의 움직인 면적과 안구의 움직인 면적 을 비교하여 계산된다. 머리의 회전자극을 병변 쪽과 반대쪽 으로 줄 때의 이득의 차이를 확인하기 위한 이득비대칭(gain asymmetry, $\mathrm{GA}$ )은 다음과 같은 공식을 이용하여 계산하였 다. 이득비대칭=[(정상 쪽을 향하는 vHIT 이득-병변 쪽을 향 하는 vHIT 이득)/(정상 쪽을 향하는 vHIT 이득+병변 쪽을 향 하는 vHIT 이득)]. $\mathrm{vHIT}$ 검사 결과의 비정상 기준은 과거에 보 
고된 정상인의 결과를 참조로 정하였으며, 이득(vHIT gain) 은 0.8 이하일 경우, 이득비대칭 $(\mathrm{GA})$ 은 0.8 이하일 경우 비정 상으로 정의하였다. ${ }^{10)}$

\section{Dizziness handicap inventory(DHI) 설문}

$\mathrm{DHI}$ 설문지는 일상생활에서 어지럼증에 의한 장애 정도를 정량화하기 위해 만들어진 검사로, 환자의 물리적(7문항), 감 정적(9문항), 기능적(9문항)인 세 환경에서 어지럼에 의한 활동 의 제약을 설문 조사를 통해 정량화한다. 각 문항에서 빈도순 으로 빈번할 경우 4점에서 0 점까지 부여한 후 합산하여 최대 제약의 경우에 100 점을, 전혀 제약이 없을 경우에는 0 점을 부 여하였다. ${ }^{18)} \mathrm{DHI}$ 검사는 어지럼증 환자의 기능적 장애 정도와 밀접한 관계를 보이며, DHI 점수의 크기가 더 커질수록 더 많은 기능적 장애를 보이는 것으로 보고된다. ${ }^{18,19)}$ 기존의 보 고를 참조하여 $\mathrm{DHI}$ 점수가 30 이내일 경우 경도(none-tomild) 어지럼증, 32 이상일 경우 중고도(moderate-to-severe) 어지럼증으로 정의하였다. ${ }^{19}$

\section{통계 분석}

급성기 및 외래추적 중에 시행한 vHIT 검사 결과 얻어진 이 득비대칭 $(\mathrm{GA})$ 값과 병변쪽으로 머리를 회전하였을 때 측정된 vHIT 이득이 어지럼증의 정도(DHI score)와 보이는 상관관 계를 확인하기 위해 선형회귀분석을 사용하였다. 또한, 경도 및 중고도의 $\mathrm{DHI}$ 점수에 따른 각 군에서의 이득비대칭 $(\mathrm{GA})$ 과 vHIT 이득의 차이를 비교하기 위해 이득의 평균값의 비교
를 위해 Mann-Whitney test를 이용하였으며, 급성기 및 외래 추적 중에 시행한 vHIT 검사에서 경도 및 중고도의 $\mathrm{DHI}$ 점 수에 따른 비정상 vHIT 결과를 보이는 비율의 비교는 Fisher's exact test를 이용하였다. 검사 결과인 $p$ 값은 0.05 이하를 통 계학적으로 의미 있는 것으로 해석하였다.

\section{결 과}

입원 중에 검사한 급성기 전정신경염 환자의 온도안진검사 의 일측마비 정도는 $69 \pm 35 \%(27 \sim 100 \%)$ 였다. 급성기의 vHIT 이득은 $0.45 \pm 0.18$ 이었으며, 외래추적검사 중에 시행한 $\mathrm{vHIT}$ 이득은 $0.70 \pm 0.25$ 로 급성기와 비교하여 의미 있게 증가하였 다 $(p<0.001)$ (Fig. 1). 입원 중에 검사한 급성기 전정신경염 환 자의 $\mathrm{vHIT}$ 이득비대칭 $(\mathrm{GA})$ 은 $0.36 \pm 0.15$ 이었으며, 외래추적 검사 결과 vHIT 이득비대칭은 $0.22 \pm 0.18$ 로 의미 있게 감소하 였으며 $(p<0.001)$, 주관적 어지럼증의 정도( $\mathrm{DHI}$ 점수)도 입원 중 $35 \pm 26$ 에서 외래 추적관찰 중 $23 \pm 23$ 으로 의미 있게 감소 하였다 $(p<0.05$, Wilcoxon signed rank test). 급성기에는 증 상이 경도(non-to-mild)인 경우가 11명이었으며, 외래관찰 시 에는 14 명으로 증가하였다. 16 명의 환자에서 overt 교정성 단 속운동이 관찰되었고, 8 명의 환자에서 covert 교정성 단속운 동이 관찰되었으며, 이러한 소견은 외래관찰 시에도 동일하게 관찰되었다.
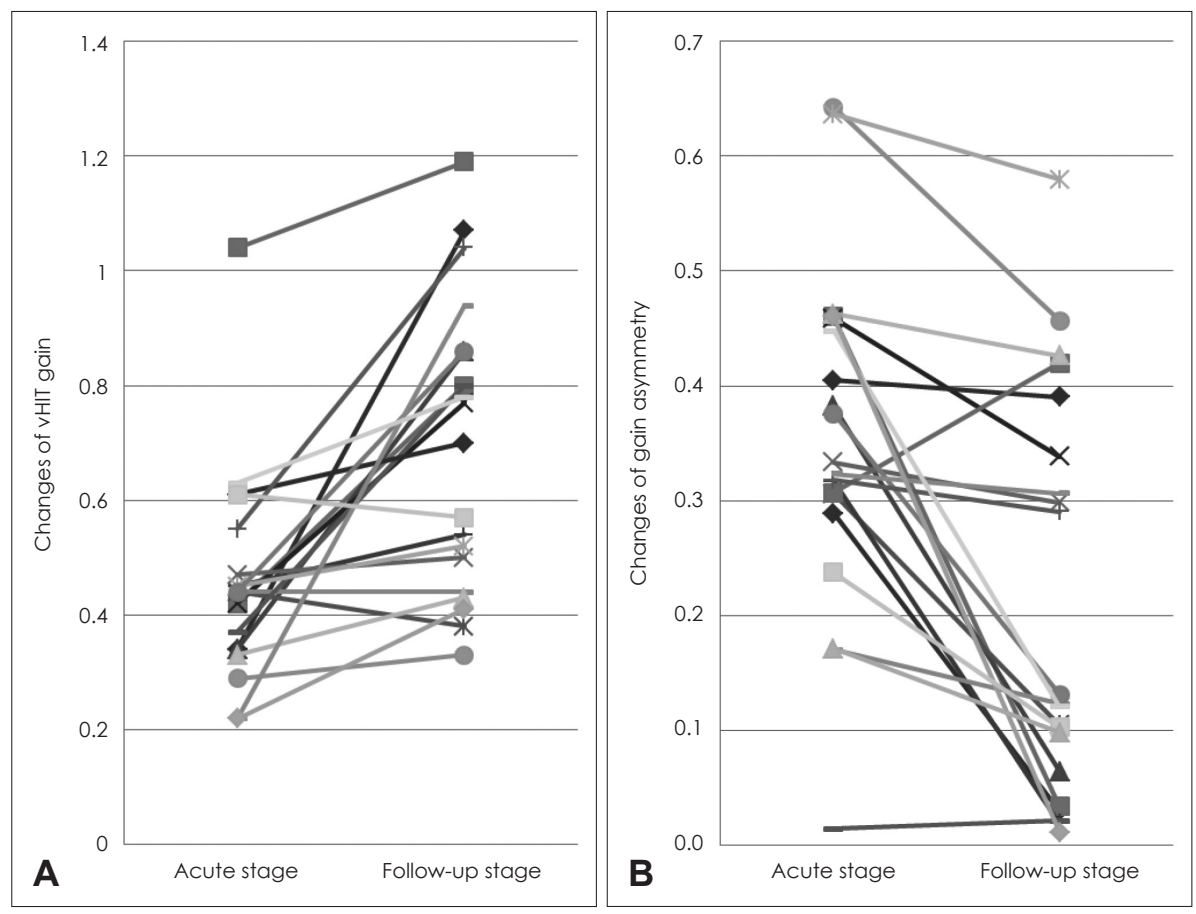

Fig. 1. Changes of VHIT gains and gain asymmetries from acute to follow-up stages. The vHIT gains (A) increased significantly at follow-up stage and gain asymmetries (B) decreased significantly at follow-up stage $(p<0.001)$. vHIT: video head impulse test. 


\section{주관적 증상과 vHIT 결과와의 상관관계}

입원 중에 검사한 급성기 전정신경염 환자에서는 $\mathrm{vHIT}$ 이 득이나 이득비대칭(GA) 모두 증상의 심한 정도(DHI 점수)와 상관관계를 보이지 않았다(Fig. 2). 급성기에 시행한 온도안진 검사의 편측마비 정도는 $\mathrm{vHIT}$ 이득이나 $\mathrm{DHI}$ 점수와 상관관 계를 보이지 않았다. 그러나, 외래 추적관찰 중에 시행한 검사 결과에서는 vHIT 이득은 환자의 주관적인 증상의 정도(DHI 점수)와 의미 있는 상관관계를 보였으며, 어지럼증의 증상이 심할수록 $\mathrm{vHIT}$ 이득이 감소하는 음의 상관관계를 보였다 ( $\mathrm{R}-\mathrm{sq}=0.3155, p<0.05)$ (Fig. 2). 그러나, 추적관찰 중의 이득 비대칭은 주관적인 증상의 정도와 의미 있는 상관관계를 보 이지 않았다.

\section{주관적 증상에 따른 vHIT 이득(gain)과 이득비대칭(gain asymmetry)의 비교}

급성기 전정신경염 환자의 경우, $\mathrm{vHIT}$ 이득이나 이득비대 칭은 어지럼증의 심한 정도에 따른 경도나 중고도의 환자군
에 따른 차이를 보이지 않았다. 그러나, 외래 추적관찰 중에 시행한 경우, 경도의 어지럼증 환자군의 vHIT 이득 $(0.78 \pm$ $0.25)$ 이 중고도 어지럼증 환자군의 $\mathrm{vHIT}$ 이득 $(0.51 \pm 0.14)$ 에 비하여 의미 있게 높았다(Fig. 3). 외래 추적관찰 중 경도의 어 지럼증 환자군과 중고도 어지럼증 환자군에서 이득비대칭은 의미 있는 차이를 보이지 않았다.

급성기와 외래추적 중 검사에서 비정상 이득을 보이는 비 율을 비교한 결과, 급성기에는 증상의 심한 정도와 무관하게 대부분의 환자에서 비정상적인 vHIT 이득을 보였다. 경도의 어지럼증 환자의 경우에는 11 명 중 10 명(91\%)에서 비정상 이 득을 보였고, 중고도 어지럼증 환자는 모두 비정상 이득을 보 였다. 외래 추적관찰 중에 시행한 vHIT 이득은 증상의 심한 정도에 따라 다른 비정상 비율을 보였다(Table 1). 경도의 어 지럼증을 호소하는 환자 14명 중 6명(43\%)에서만 비정상 이 득을 보였으나 중고도의 어지럼증을 호소하는 환자 6 명 모 두 비정상적인 이득을 보여, 두 군 간의 비정상 이득을 보이는 비율이 의미 있게 달랐다 $(p<0.05)$ (Table 1).
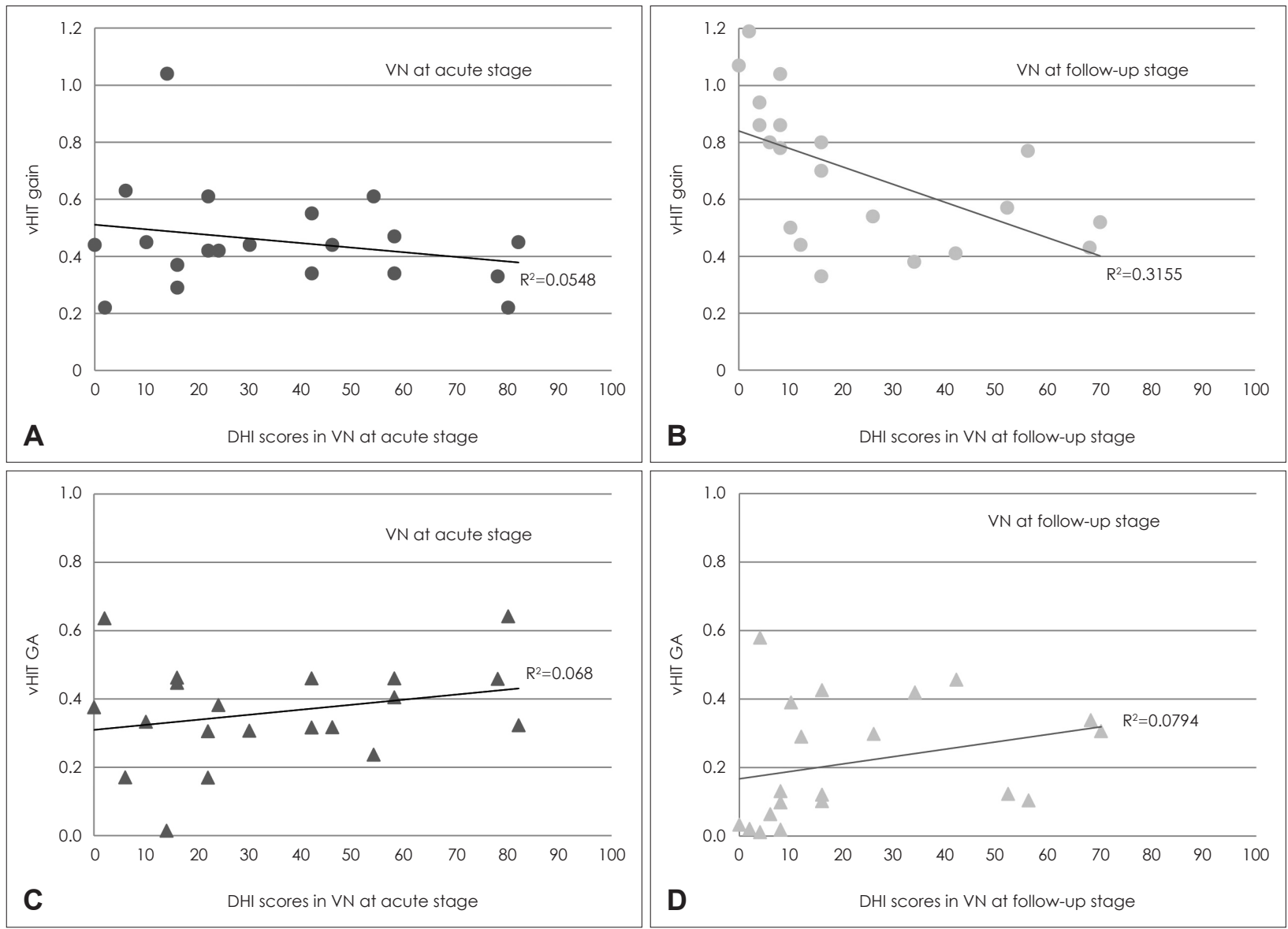

Fig. 2. Pearson correlation plot between $D H I$ scores and vHIT gain ( $A$ and $B$ ) and $G A(C$ and $D)$ in patients with VN at acute and followup stages. DHI scores shows significant negative correlation with only vHIT gain in patients with VN at follow-up stage $(B, R$-sq $=0.3155$, $p<0.05)$. No correlation was found between DHI scores and vHIT gain at acute stage (A), and GA at acute and follow-up stages (C and D). DHI: dizziness handicap inventory, vHIT: video head impulse test, VN: vestibular neuritis, GA: gain asymmetry. 

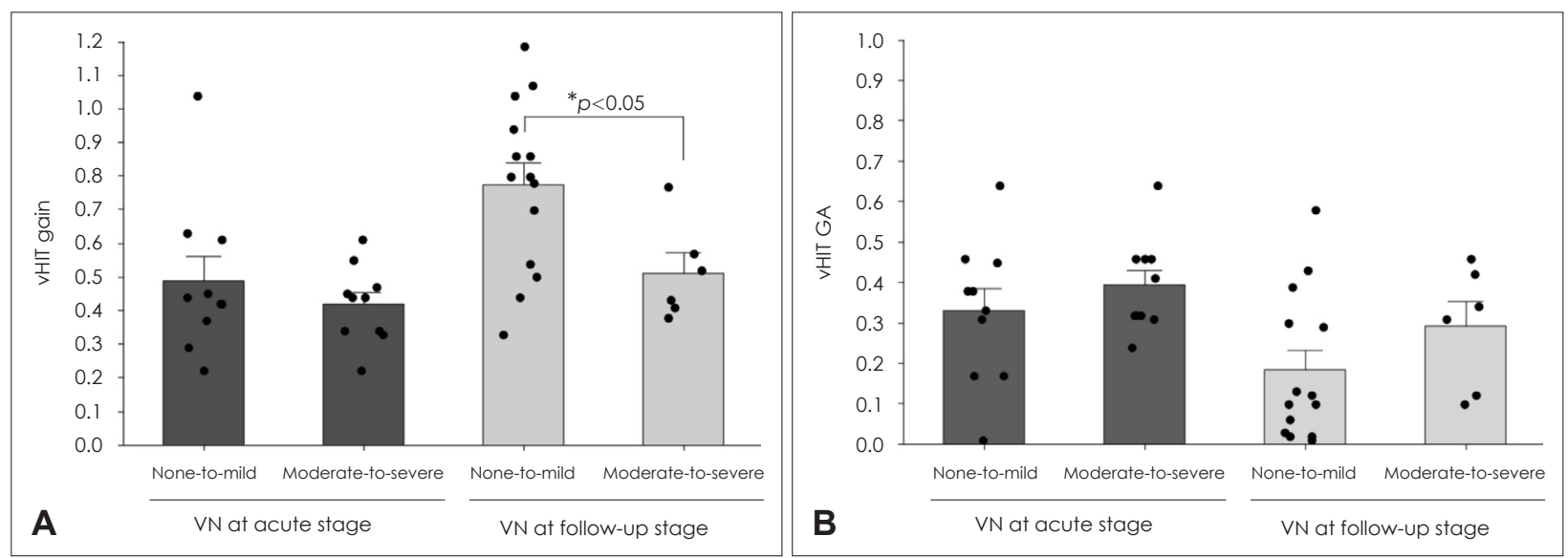

Fig. 3. vHIT gains (A) and gain asymmetries (B) in VN patients with none-to-mild and moderate-to-severe $\mathrm{DHI}$ scores. The mean vHIT gain of VN patients with none-to-mild $\mathrm{DHI}$ scores was significantly higher than that of VN patients with moderate-to-severe $\mathrm{DHI}$ scores only at follow-up stage $(A, p<0.05)$. This relationship was not significant at acute stage. Patients with none-to-mild DHI scores showed less GA than patients with moderate-to-severe DHI scores, though it was not significant (B). *Mann-Whitney test. DHI: dizziness handicap inventory, vHIT: video head impulse test, VN: vestibular neuritis, GA: gain asymmetry.

Table 1. Abnormal rates in VHIT gain value in patients with VN at acute and follow-up stages

\begin{tabular}{lccc}
\hline & Decreased vHIT gain (vHIT gain $\leq 0.8)$ & Normal vHIT gain (vHIT gain $>0.8)$ & $p$-value* \\
\hline $\begin{array}{l}\text { VN at acute stage }(\%) \\
\text { None-to-mild dizziness }\end{array}$ & $10(91)$ & $1(9)$ & 1.0 \\
Moderate-to-severe dizziness & $9(100)$ & 0 & \\
VN at follow-up stage $(\%)$ & & $8(57)$ \\
None-to-mild dizziness & $6(43)$ & 0 & $<0.05$ \\
Moderate-to-severe dizziness & $6(100)$ &
\end{tabular}

*Fisher's exact test. vHIT: video head impulse test, VN: vestibular neuritis

\section{고 찰}

비디오 두부충동검사는 고주파수, 고가속도 머리의 회전운 동 중 시력을 유지하는 데 필수적인 반사적인 안구운동을 일 으키는 전정안반사의 기능을 확인하는 검사법이다. 고주파 수, 고가속도 머리의 회전운동을 자극으로 하며 비디오 안구 운동측정장비를 이용 안구의 운동을 기록하는 비디오 두부 충동검사는 경부안반사나 시각운동계 등 다른 반사를 통한 영향을 최소한으로 하며 전정안반사의 기능을 평가할 수 있 는 도구로서의 임상적 의의를 가지며, 낮은 주파수.가속도의 회전 자극에 대한 전정안반사를 대변하는 온도안진검사와 함께 전정질환의 병태생리와 보상기전의 추적 검사, 그리고 각종 치료 방법의 효과 판단 등 많은 관점에서 전정질환을 이해하는 데 큰 도움을 주는 검사이다. ${ }^{1-3,5)}$

본 연구에서는 어지럼증의 심한 정도를 비교하기 위해 $\mathrm{DHI}$ 점수를 사용하였다. $\mathrm{DHI}$ 설문은 어지럼증과 연관된 환 자의 장애를 수치화한 검사법으로, 어지럼증을 호소하는 환 자에서 효과적으로 어지럼증을 객관화할 수 있는 도구로 보 고된다. ${ }^{20,21)}$ 본 연구에서는 급성기 전정신경염 환자에서는 한 명을 제외한 모든 환자에서 비정상적인 vHIT 결과를 보여
증상의 심한 정도에 따른 차이를 확인하기 어려웠지만, 약 5 주 이후의 외래 추적관찰 중에 시행한 검사 결과 어지럼증의 증상이 심할수록 vHIT 이득이 낮은 음의 상관관계를 보이 고, 어지럼증 증상이 심한 환자가 경도의 어지럼증을 호소하 는 환자보다 더 낮은 vHIT 이득을 보였고 비정상적인 $\mathrm{vHIT}$ 이득을 보일 가능성이 더 높았다. 이는 어지럼증의 초기에는 동적인 전정기능의 손상뿐 아니라 자발 안진 등 정적인 전정 기능의 손상에 의한 전정기능의 이상도 환자의 어지럼증에 영 향을 주는 것으로 설명할 수 있다. 전정신경염에 의한 정적인 전정불균형은 전정안반사의 손상에 의한 동적인 불균형보다 보다 빨리 호전되는 것으로 보고되며,22) 따라서 급성기를 지 남에 따라 vHIT 이득의 감소와 같은 동적 전정불균형이 상 대적으로 환자의 전정기능의 이상에 따른 어지럼증의 유발에 기여하고 따라서 이러한 관계를 확인할 수 있게 되는 것으로 추정할 수 있다.

현재까지 보고된 연구에 의하면, $\mathrm{vHIT}$ 검사 결과와 어지럼 증 증상의 심한 정도와의 연관성이 모든 연구에서 확인되지 는 않는 것으로 보고된다. 본 연구에서도 외래추적 중에 이러 한 수평반고리관에서의 vHIT 이득의 변화가 어지럼증의 정도 를 모두 설명하기보다는 약 $32 \%$ 정도를 설명할 수 있는 것으 
로 확인된다. 전정기관은 세 반고리관과 두 개의 이석기관으 로 이루어져 있어 각 기관별로 손상된 정도에 따라 어지럼증의 정도 차이가 날 것으로 유추할 수 있다. 최근의 보고에 의하면, 전정신경염에 의한 어지럼증이 발생한지 4 8주 후에 시행한 검사에서 본 연구의 결과와 유사하게 $\mathrm{DHI}$ 점수(어지럼증의 정도)는 $\mathrm{vHIT}$ 이득이 감소할수록(수평 전정안반사의 이득 이 감소할수록) 증가하는 것으로 보고된다. ${ }^{15)}$

그러나, 전정신경염을 않은 환자에서 지속적으로 남은 어지 럼증과 자세불안은 $\mathrm{vHIT}$ 검사 결과와 상관관계를 보이지 않 는다는 상반된 연구 결과도 있다. 기존의 한 연구에서는 vHIT 결과와 증상과 연관관계가 없다고 하였으며, ${ }^{23)}$ 이 연구는 어 지럼증의 심한 정도를 Yardley vertigo symptom scale short form을 이용하여 본 연구와 다른 결과를 얻을 수도 있으리 라 생각된다. 증상이 발생한지 3개월 이상인 전정신경염 20 명에서 $\mathrm{vHIT}$ 검사 결과와 $\mathrm{DHI}$ 점수를 비교한 다른 연구에 의하면, vHIT 이득이나 이득비대칭, 온도안진검사의 일측마 비 정도와 어지럼증의 정도는 상관관계를 보이지 않는 것으 로 보고된다. ${ }^{24)}$ 또한, 다양한 전정질환을 호소하는 환자에서 vHIT 검사 결과와 증상의 정도와는 관계가 없다는 보고도 있 으나,16) 이러한 다양한 질환군의 포함이 $\mathrm{vHIT}$ 검사 결과와 증 상의 정도와는 관계가 없다는 결과를 내는데 역할을 할 수 있을 것으로 생각되며, 전정기능 이상 이외에는 다른 문제가 없는 환자군만을 대상으로 하는 것이 상관관계를 보다 정확 히 판단을 하는데 도움을 줄 수 있을 것으로 생각된다. 또 다 른 보고에 의하면, 어지럼증의 증상은 온도안진검사 결과에 따른 반고리관 기능의 손상 정도(canal paresis)와는 무관하고, 동적평형검사(posturography)에서의 이상 여부에 영향을 받 아 DHI 점수는 전정안반사의 이상보다는 전정척수반사의 이 상에 의해 더 영향을 받는다는 보고도 있다. ${ }^{25)}$ 따라서, 전정신 경염 환자에서 증상이 발생한 시기에 따른 대규모의 환자군 을 대상으로 다양한 전정기관의 이상을 확인할 수 있는 검사 의 결과와 증상의 심한 정도를 종합적으로 확인하는 추가적 인 연구가 필요할 것으로 생각된다.

전정신경염 환자의 치료에 있어서 전정재활치료의 역할은 매우 중요한 것으로 보고되며, ${ }^{26)}$ 전정재활운동을 통해 의미 있는 기능적 호전을 보임이 보고된다. 전정안반사와 전정척수 반사의 회복의 기전으로는 중추성 안구운동 및 자세유지반 응의 재구성이나, 경부-안반사, 보상성 단속운동, 시각 및 체 성감각을 이용한 보상 등의 기전이 있으나, 전정재활운동을 통한 손상된 전정기능의 회복이 어지럼증 증상의 호전과 기 능적 회복에 있어서 가장 중요한 기전으로 보고된다. ${ }^{14)}$ 임상 적으로 전정신경염 환자에서 전정안반사의 소실 정도와 어지 럼증 증상의 정도와의 연관성을 확인함으로써 전정기능검사
결과를 이용하여 전정재활치료의 필요성을 추정할 수 있다 는 보고가 있어, $\left.{ }^{15}\right)$ 비디오 두부충동검사의 결과와 어지럼증 증 상의 정도와의 연관성이 보다 명확히 확인될 경우, 비디오 두 부충동검사 결과는 전정재활운동의 필요성을 확인하기 위해 객관적인 지표로써 사용될 수 있는 장점이 있으리라 생각된 다. 본 연구에서 질환의 초기에는 측반고리관의 손상되는 정 도(온도안진검사나 비디오 두부충동검사결과)와 $\mathrm{DHI}$ 의 점 수와는 의미 있는 상관관계를 보이지 않아 급성기에는 환자 가 증상의 경중도를 판단하는 것은 환자의 개인적인 주관적 판단기준에 따라 다르다고 해석할 수 있다. 반면, 외래 추적 관찰 시에 $\mathrm{vHIT}$ 이득 값이 호전된 경우에는 대부분의 환자가 증상이 심하지 않은 것으로 판단하는 경우가 많은 경우로 보 아, 외래 추적관찰 중 비디오 두부충동검사 결과를 참조하여 환자의 재활치료 여부를 결정하는 것이 좋을 것으로 생각된 다. 물론, 이러한 판단에는 비디오 두부충동검사 결과뿐 아니 라 다른 임상적 소견과 종합적으로 판단하여 환자의 전정재 활의 필요성 여부를 판정하는 것이 좋을 것으로 생각된다.

결론적으로, 급성기의 전정신경염 환자에서는 vHIT 검사 결과가 어지럼증 증상의 심한 정도와 상관관계가 없었으나, 외래 추적관찰 중에 시행한 $\mathrm{vHIT}$ 이득은 어지럼증 증상이 심할수록 더 낮은 소견을 보였으며, 어지럼증 증상이 심한 환 자는 증상이 경도인 환자에 비교하여 vHIT 이득 자체의 크 기도 낮았다. 따라서, 외래에서 쉽게 시행할 수 있는 vHIT 검 사는 어지럼증을 호소하는 환자에서 전정기능 이상을 확인 하고 어지럼증 증상과의 연관성을 잘 보여줄 수 있음을 알 수 있다. 비디오 두부충동검사는 전정기능의 재활을 통한 전정 기능의 호전을 통해 어지럼증 증상이 호전되는데 도움을 받 을 수 있는 환자를 확인하는데 객관적인 지표로써 사용될 수 있으리라 생각된다.

\section{ORCID}

Hong Ju Park https://orcid.org/0000-0002-6331-8556

\section{REFERENCES}

1) Halmagyi GM, Curthoys IS. A clinical sign of canal paresis. Arch Neurol 1988;45(7):737-9.

2) MacDougall HG, Weber KP, McGarvie LA, Halmagyi GM, Curthoys IS. The video head impulse test: diagnostic accuracy in peripheral vestibulopathy. Neurology 2009;73(14):1134-41.

3) Park HJ. Vestibulo-ocular reflex for high frequency and acceleration head rotation. Korean J Otorhinolaryngol-Head Neck Surg 2006; 49(4):356-65.

4) Agrawal Y, Schubert MC, Migliaccio AA, Zee DS, Schneider E, Lehnen N, et al. Evaluation of quantitative head impulse testing using search coils versus video-oculography in older individuals. Otol Neurotol 2014;35(2):283-8.

5) Aw ST, Haslwanter T, Halmagyi GM, Curthoys IS, Yavor RA, Todd MJ. Three-dimensional vector analysis of the human vestibuloocular 
reflex in response to high-acceleration head rotations. I. Responses in normal subjects. J Neurophysiol 1996;76(6):4009-20.

6) Kim DY, Choi YG, Kyung TS, Hwang JH, Kim HJ, Lee SC, et al. Causes of false negative bedside head impulse test. Korean J Otorhinolaryngol-Head Neck Surg 2017;60(3):107-11.

7) Yoo MH, Kim SH, Lee JY, Yang CJ, Lee HS, Park HJ. Results of video head impulse and caloric tests in 36 patients with vestibular migraine and 23 patients with vestibular neuritis: a preliminary report. Clin Otolaryngol 2016;41(6):813-7.

8) Weber KP, Aw ST, Todd MJ, McGarvie LA, Curthoys IS, Halmagyi GM. Head impulse test in unilateral vestibular loss: vestibulo-ocular reflex and catch-up saccades. Neurology 2008;70(6):454-63.

9) Matiño-Soler E, Esteller-More E, Martin-Sanchez JC, MartinezSanchez JM, Perez-Fernandez N. Normative data on angular vestibuloocular responses in the yaw axis measured using the video head impulse test. Otol Neurotol 2015;36(3):466-71.

10) Yang CJ, Lee JY, Kang BC, Lee HS, Yoo MH, Park HJ. Quantitative analysis of gains and catch-up saccades of video-head-impulse testing by age in normal subjects. Clin Otolaryngol 2016;41(5):532-8.

11) Yoo MH, Yang CJ, Kim SA, Park MJ, Ahn JH, Chung JW, et al. Efficacy of steroid therapy based on symptomatic and functional improvement in patients with vestibular neuritis: a prospective randomized controlled trial. Eur Arch Otorhinolaryngol 2017;274(6): 2443-51.

12) Magliulo G, Iannella G, Gagliardi S, Re M. A 1-year follow-up study with C-VEMPs, O-VEMPs and video head impulse testing in vestibular neuritis. Eur Arch Otorhinolaryngol 2015;272(11):3277-81.

13) Kammerlind AS, Ledin TE, Skargren EI, Odkvist LM. Long-term follow-up after acute unilateral vestibular loss and comparison between subjects with and without remaining symptoms. Acta Otolaryngol 2005;125(9):946-53.

14) Herdman SJ. Role of vestibular adaptation in vestibular rehabilitation. Otolaryngol Head Neck Surg 1998;119(1):49-54.

15) Cerchiai N, Navari E, Sellari-Franceschini S, Re C, Casani AP. Predicting the outcome after acute unilateral vestibulopathy: analysis of vestibulo- ocular reflex gain and catch-up saccades. Otolaryngol Head Neck Surg 2018;158(3):527-33.

16) Yip CW, Strupp M. The dizziness handicap inventory does not correlate with vestibular function tests: a prospective study. J Neurol 2018;265 (5):1210-8.

17) Redondo-Martínez J, Bécares-Martínez C, Orts-Alborch M, GarcíaCallejo FJ, Pérez-Carbonell T, Marco-Algarra J. Relationship between video head impulse test (vHIT) and caloric test in patients with vestibular neuritis. Acta Otorrinolaringol Esp 2016;67(3):156-61

18) Jacobson GP, Newman CW. The development of the dizziness handicap inventory. Arch Otolaryngol Head Neck Surg 1990;116(4):424-7.

19) Whitney SL, Wrisley DM, Brown KE, Furman JM. Is perception of handicap related to functional performance in persons with vestibular dysfunction? Otol Neurotol 2004;25(2):139-43.

20) Fong E, Li C, Aslakson R, Agrawal Y. Systematic review of patientreported outcome measures in clinical vestibular research. Arch Phys Med Rehabil 2015;96(2):357-65.

21) Lee WS, Lee YH, Hong JP, Kwon OW, Chung WK. Vestibular rehabilitation in incompletely compensated acute unilateral vestibular loss. Korean J Otorhinolaryngol-Head Neck Surg 2001;44(3):256-60.

22) Choi KD, Oh SY, Kim HJ, Koo JW, Cho BM, Kim JS. Recovery of vestibular imbalances after vestibular neuritis. Laryngoscope 2007; 117(7):1307-12.

23) Palla A, Straumann D, Bronstein AM. Vestibular neuritis: vertigo and the high-acceleration vestibulo-ocular reflex. J Neurol 2008;255(10): 1479-82.

24) Patel M, Arshad Q, Roberts RE, Ahmad H, Bronstein AM. Chronic symptoms after vestibular neuritis and the high-velocity vestibuloocular reflex. Otol Neurotol 2016;37(2):179-84.

25) Shim DB, Song MH, Park HJ. Typical sensory organization test findings and clinical implication in acute vestibular neuritis. Auris Nasus Larynx 2018;45(5):916-21.

26) Strupp M, Arbusow V, Maag KP, Gall C, Brandt T. Vestibular exercises improve central vestibulospinal compensation after vestibular neuritis. Neurology 1998;51(3):838-44. 